\title{
GYERGYÓSZENTMIKLÓS ÉS NYÍREGYHÁZA LAKOSSÁGÁNAK TESTTÖMEG INDEX JELLEMZŐI
}

\author{
Magyari Anna, Dégi László Csaba
}

\begin{abstract}
Body Mass Index characteristics of the population in Gyergyószentmiklós and Nyíregyháza. This study is examining factors influencing quality of life in Gyergyószentmiklós (Romania) and Nyíregyháza (Hungary) with special focus on BMI characteristics and differences of the participants in this sample. Obesity, overweight are among main risk factors for cardio-vascular diseases. For this reason the connection between BMI and cardio-vascular diseases is discussed. There are different, other biological, psychological and environmental factors in the background of cardio-vascular diseases but in this research, based on the Household Panel Questionnaire developed by the University of Debrecen, Faculty of Health they are not covered. 309 adult subjects from Gyergyószentmiklós and 107 from Nyíregyháza responded. Results show a comparative picture of the BMI characteristics of the participants in this sample.
\end{abstract}

Kivonat: A fejezet Gyergyószentmiklós (Románia) és Nyíregyháza (Magyarország) városok lakóinak életminőségét befolyásoló tényezöit vizsgálja, kiemelve a mintában résztvevők testtömeg indexének jellegzetességeit és eltéréseit. A kutatáshoz használt kérdöív érinti a lakosság lakáskörülményeire, szubjektív és objektív egészségi állapotára, szüréseken való részvételére vonatkozó adatokat. A tanulmány középpontjában a vizsgált mintában résztvevő gyergyószentmiklósi és nyíregyházi lakosság testtömeg indexének változásai állnak a kor és a nem függvényében, majd az agyi-, szív-érrendszeri betegségekhez viszonyított jelentőségét vizsgáljuk.

DOI: $10.19055 / \mathrm{ams} .2013 .4 / 10 / 10$

\section{BEVEZETÉS}

A gyergyószentmiklósi kérdőívek eredményeinek a bemutatása elött, fontos a romániai, Hargita megyei lakosság egészségére vonatkozó adataira is kitérni. Országos szinten eddig öt alkalommal végeztek egészségfelmérő kutatást: 1959-ben,1964-ben, 1983-ban, 1989-ben és 1997-ben, azonban a kutatások eredményeit nem tették elérhetővé az ország lakosságának (Tar és Ábrám, 2012). 
2007-ben a „Az Országos Egészségfelmérő Program” keretén belül országos epidemiológiai vizsgálatot indítottak el, amelyben az ország lakosságot felkérték, hogy jelenjenek meg családorvosaiknál és vegyenek részt egy ingyenes általános klinikai-, és laboratóriumi vizsgálaton, függetlenül attól, hogy rendelkeznek-e kötelező egészségügyi biztosítással. Az adatgyüjtés 2009-ben ért véget, de mivel az egészségfelmérés nagy költségekkel indult és számos módszertani probléma jelent meg a teljes adatfeldolgozás nem valósult meg. Dr. Tar Gyöngyvér és prof. Dr. Ábrám Zoltán (2012) „A romániai Országos Egészségfelmérő Program jelentősége és Hargita megyei vonatkozásai" kutatásban 150 Hargita megyében dolgozó családorvos kérdőives felmérését végezték el. A felmérés középpontjában a családorvosok országos lakossági egészségfelméréséről, használhatóságáról alkotott véleménye áll. A felkeresett orvosok $68 \%$-a akkor elvégzett laboratóriumi vizsgálatok eredményeit jelenleg is használja, 99\%-a úgy véli, hogy a felmérés a páciensek körében a korai diagnosztizálását szolgálta.

Az Európai Unió hivatalos statisztikái alapján a 27 tagállamban a leggyakrabban előforduló halálok a keringési rendszer betegségei és a rosszindulatú daganatok. Mivel a tanulmány középpontjában a vizsgált mintához tartozó lakosság testtömeg index változásai állnak, a testtömeg index pedig szoros összefüggésben van a cukorbetegséggel, szív-érrendszeri betegségekkel, magas vérnyomással, egyes daganattípusokkal ezért az alábbi összefoglaló táblázatban (1. táblázat) a felsorolt betegségek okozta halálozási arányt figyelhetjük meg az Európai Unió 27 tagállamában (továbbiakban EU-27), Magyarországon és Romániában (Eurostat, 2013).

A táblázatból körvonalazódik, hogy Románia és Magyarország lakosságának a különböző betegségek által elöidézett halálozási aránya jóval magasabb, mint az EU-27 országainak átlaga. Romániában a legnagyobb eltérést az EU átlagától a keringési rendszer megbetegedései, a szívbetegségek és a méhrák esetében figyelhetünk meg. Magyarország és az EU-27 átlagértékei között a legnagyobb eltérés a szívbetegségek, a keringési rendszer betegségei, a tüdörák és a daganatos betegségek között van.

Dr. Ábrám Zoltán és Dr. Tar Gyöngyvér kutatásaikban (2012) a székelyföldiek egészségi állapotának vizsgálatára fektetik a hangsúlyt, amelyből kiderül, hogy Székelyföld férfi lakosságának leggyakoribb haláloka a tüdődaganat. Felmérésük $(\mathrm{N}=155)$ alapján a leggyakrabban előforduló betegségtípusok a férfi és női lakosság esetében a szív-érrendszer betegségek, ebben a megkérdezettek 59 \%-a szenved, ezt követik a csont-, izomrendszeri és ízületi betegségek (22\%). A harmadik helyen az idegrendszeri betegségek (14\%) állnak. A kutatók három székelyföldi megyeközpontban, Csíkszeredában, Sepsiszentgyörgyön és Marosvásárhelyen a depresszióra való hajlamot mérték fel, ebből kiderül, hogy a megkérdezettek 57\%-a nem depressziós, $21 \%$-a enyhe depresszió tüneteit mutatja, 9.4\%-uk közepes depresszióban szenved, 11.1\%-nál súlyos depresszió figyelhetö meg. 
1. Táblázat: Halálokok - 100.000 lakosra jutó halálozási arányszám az Európai Unióban, Romániában és Magyarországon

\begin{tabular}{|l|l|l|l|l|}
\hline $\begin{array}{l}\text { Forrás: Eu- } \\
\text { rostat, 2013 }\end{array}$ & EU-27 & Románia & Magyarország \\
\hline Összesen & $\begin{array}{l}\text { Daganatos } \\
\text { betegségek }\end{array}$ & 169,0 & 181,4 & 234,2 \\
\hline & Tüdőrák & 38,6 & 42,3 & 70,5 \\
\hline & Végbélrák & 18,9 & 19,5 & 34,8 \\
\hline & $\begin{array}{l}\text { A keringési } \\
\text { rendszer } \\
\text { betegségei }\end{array}$ & 217,3 & 548,4 & 421,2 \\
\hline & Szívbetegségek & 79,8 & 188,8 & 214,8 \\
\hline & $\begin{array}{l}\text { Légzőrendszer } \\
\text { betegségei }\end{array}$ & 43,6 & 50,6 & 44,3 \\
\hline Nők & $\begin{array}{l}\text { Közlekedési } \\
\text { balesetek }\end{array}$ & 7,4 & 50,6 & 44,3 \\
\hline & Emlörák & 23,1 & 22,6 & 28,1 \\
\hline & Méhrák & 7,2 & 17,4 & 10,3 \\
\hline
\end{tabular}

Elemzésünkben a vizsgált minta testtömeg indexét (továbbiakban TTI) tanulmányozzuk, kitérve a TTI nem, kor, lakhely és agyi-, szív- érrendszeri betegségek kapcsolatára. Az agyi-, szív- érrendszeri betegségek kialakulásában számos bio-, pszicho-, szociális tényező szerepet játszik, azonban ebben a tanulmányban nem részleteződnek a betegség hátterében található összetevők. Az elhízás a WHO (Egészségügyi Világszervezet) szerint egyike a jelenlegi legnagyobb egészségügyi problémáinak, amely ugyanúgy érinti a gazdaságilag fejlett országokat, mint a fejletleneket. Az Európai Unióban 2010-ben 150 millió felnőtt és 15 millió gyermeket érint az elhízás, ez pedig a II-es típusú cukorbetegségek $80 \%$ - ért, az ischaemiás szívbetegségek 35\%-ért, a magas vérnyomás $55 \%$-ért felelős (Tsigos, Heiner, Basdevant és mtsai, 2008).

A testtömeg index (rövidítve TTI) egy méröszám, amely a felnőttek testmagasságát és súlyát veti össze. A TTI a soványság, túlsúly és elhízás megállapítására szolgál. A 2. Táblázatban a WHO szerinti TTI felosztást láthatjuk.

Az Eurostat (2008) adatai szerint Magyarország felnőtt lakosságának 53,2\%-a elhízott ( $\geq 25.00$ ), 17.7 \%-túlsúlyos ( $\geq 30.00$ ), Románia felnőtt lakosságának pedig 41,7\%a túlsúlyos, $8,7 \%$-a pedig elhízott. 
A statisztikák alapján elmondható, hogy Románia és Magyarország az elhízás tekintetében sem kivételek, melynek súlyos következményei vannak a lakosság egészségi állapotára és életminőségére.

2. Táblázat: A testtömeg index kategóriák. Forrás: WHO, 2004

\begin{tabular}{|l|l|}
\hline Osztályozás & TTI $(\mathrm{kg} / \mathrm{m} 2)$ \\
\hline Soványság & $<18.50$ \\
\hline Súlyos soványság & $<16.00$ \\
\hline Mérsékelt soványság & $16.00-16.99$ \\
\hline Enyhe soványság & $17.00-18.49$ \\
\hline Normális testsúly & $18.50-24.99$ \\
\hline Túlsúlyos & $\geq 25.00$ \\
\hline Elhízás (előtti) & $25.00-29.99$ \\
\hline Elhízás & $\geq 30.00$ \\
\hline I. fokú elhízás & $30.00-34.99$ \\
\hline II. fokú elhízás & $35.00-39.99$ \\
\hline III. fokú elhízás & $\geq 40.00$ \\
\hline
\end{tabular}

3. Táblázat: Gyergyószentmiklós lakosságának életkor struktúrája 2012-ben. Forrás: INSSE, 2013

\begin{tabular}{|l|c|}
\hline Korcsoport & Összesen \\
\hline $0-19$ & 3939 \\
\hline $20-39$ & 6203 \\
\hline $40-59$ & 5724 \\
\hline $60-79$ & 3258 \\
\hline 80 fölött & 525 \\
\hline
\end{tabular}

\section{GYERGYÓSZENTMIKLÓS RÖVID BEMUTATÁSA}

Gyergyószentmiklós lakónépesség száma alapján Hargita megye harmadik legnagyobb városa, Csíkszereda és Udvarhely városok után. Összlakossága, a KSH adatok alapján, 
2012 január 1-én 19.666 fő volt, ez jóval kevesebb Nyíregyháza lakosságánál, ahol 2011 elején 118 ezren éltek (Fábián, Patyán, Huszti, 2012). A lakosság nemek szerinti összetétele alapján, Gyergyószentmiklóson jelenleg 10.124 nő és 9544 férfi él (INSSE Hargita, 2013).

A város lakosságának korszerkezete a 3. táblázatban van összefoglalva.

Etnikai hovatartozás szempontjából Gyergyószentmiklós 87,08 \%-a magyar nemzetiségünek vallotta magát, 10,41\%-a román nemzetiségünek, 2,55\%-a pedig a roma kisebbséghez tartozónak vallotta magát (INSSE Harghita, 2013). Nyíregyházán 2001ben a város lakosságának 1,6 \%- a roma nemzetiségü (Fábián, Patyán, Huszti, 2012).

\section{A MintáRól}

A kutatáshoz a Debreceni Egyetem Egészségügyi Kara által összeállított „Életminőségháztartáspanel" kérdőivet használtuk fel, melyet összesen 308 gyergyószentmiklósi (202) és nyíregyházi (106) 18 év fölötti lakos töltötte ki. A két város kiválasztásánál figyelembe vettük, hogy mindkét város esetében hasonló magyar környezetröl beszélünk.

A gyergyószentmiklósi minta a gyergyószentmiklósi össznépesség 1,02 \%- át teszi ki, a nyíregyházi minta pedig a nyíregyházi lakosság 0,08 \%-át reprezentálja. A gyergyószentmiklósi minta kiválasztásánál első lépésben az alábbi csoportokra osztottuk fel a 18-60 közötti korcsoportot: 18-30 év, 30-40 év, 40-50 év, 50-60 év. A csoportosítást azért tartottuk szükségesnek, hogy mindegyik csoportban egységesen 50 személy vegyen részt, ezáltal mindegyik korcsoport egyenlő arányban szerepel a mintánkban. A kutatásban résztvevő gyergyószentmiklósi minta átlagéletkora így 40,8 év. A kérdöívek kitöltésére több helyszínen került sor: egy ifjúsági szervezetnél, egy varrodában, tanügyi és egy egészségügyi intézményben.

1. Ábra. A minta nemek szerinti összetétele (\%)

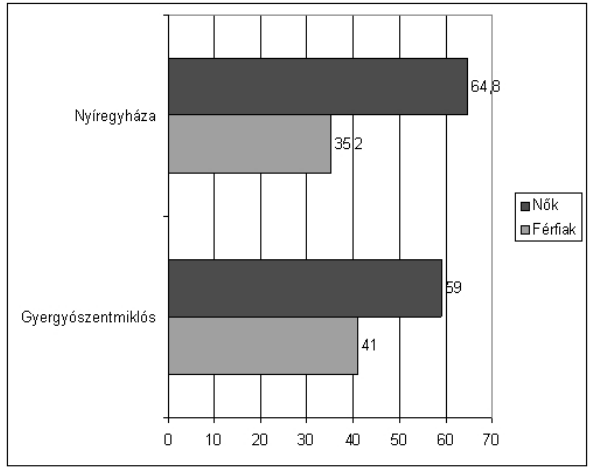


A helyszínek kiválasztásakor az intézmények/szervezet vezetőjével elözetesen megvizsgáltuk a munkavállalók/klienscsoport összetételét, kor, nem iskolai végzettség szerint, a minta heterogenitására törekedve. A kérdőívek kitöltésére egy hét állt a válaszadók rendelkezésére, amelyet személyesen vettünk át a határidő lejárta után, lehetőséget adva a válaszadóknak a számukra nem érthető részek megbeszélésére.

A gyergyószentmiklósi és nyíregyházi mintában egyaránt több nő szerepel, mint férfi. Gyergyószentmiklóson a válaszadók 59,0\%-a nő, és 41\%-a férfi, Nyíregyházán pedig ez az arány $64,8 \%$ és $35,2 \%$. (1. ábra)

A kutatásban résztvevők korát illetően megállapíthatjuk, hogy a nyíregyházi válaszadók átlag életkora 46,95, ez 6,09-al több a gyergyói minta átlagéletkoránál $(40,8)$. A kutatás egyik korlátaként értelmezhetjük az átlagéletkorok közötti különbséget, hiszen a különböző betegségek előfordulásának kockázata a kor elörehaladtával nő és a testtömeg index értékét is befolyásolja.

Az iskolai végzettséget tekintve, a gyergyószentmiklósi mintában magasabb iskolai végzettséggel rendelkeznek, mint a nyíregyházi mintában. A gyergyószentmiklósiak 39,6 \%-a egyetemmel, 19,8\%-a föiskolával rendelkezik, szemben a nyíregyháziakkal, ahol a vizsgált minta 4,7\%-a egyetemi-, 25,2\%-a pedig föiskolai végzettségü. A két város között, iskolai végzettséget vizsgálva szignifikáns különbséget találunk, a khi négyzet próba alapján $(\mathrm{p}=0,00)$ (kisebb, mint 0,05$)$. A kérdőívben megadott iskolatípusok mindkét országban megtalálhatóak, annyi különbséggel, hogy Romániában a szakmunkásképzö és szakközépiskola összevont formában müködik. (2. ábra)

2. Ábra. A minta iskolai végzettség szerinti összetétele (\%)

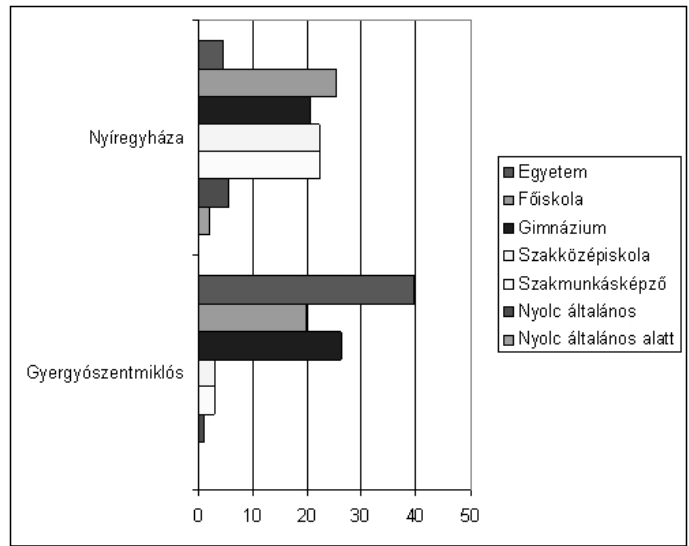

A gyergyószentmiklósi és nyíregyházi minta családi állapotát megvizsgálva nem találunk szignifikáns különbséget a két csoport között, a kérdőívet kitöltő gyergyószentmiklósiak 58,7\%-a, a nyíregyháziak 62,3\%-a házastársi kapcsolatban él. Az élettársi kapcsolat a 
vizsgált minta alapján egyik településen sem elterjedt, ugyanis a gyergyószentmiklósi válaszadók 8\%-a, nyíregyháziak 5,7\%-a választotta ezt az együttélési formát.

Összegzésként elmondható, hogy a kutatásban 309 személy vett részt, 202 személy Gyergyószentmiklósról, 107 személy pedig Nyíregyházáról. A kutatás egyik korlátja, hogy a két minta átlagéletkora között 6 év különbség van, és a betegségek kialakulásának egyik legfontosabb kockázati tényezője a kor.

\section{A TESTTÖMEg INDEX JELLEMZÖI A VIZSGÁLT MINTÁBAN}

Meghatározás szerint az elhízás az energiaháztartás módosulása, amely az táplálékfelvétel növekedésében és/vagy az energia leadás csökkenésében nyilvánul meg és ez zsírraktározáshoz vezet. Az elhízásban jelentős szerepet játszanak az anyagcsere- folyamatok genetikai, központi idegrendszeri, endokrin és környezeti hatásokra létrejövő zavarai. (Belgyógyászati Szakmai Kollégium és Magyar Elhízástudományi Társaság, 2008) Az utóbbi harminc évben az elhízás járványszerủ méreteket öltött, népegészségügyi jelentősége elérte a dohányzásét, ez pedig hatalmas kihívást jelent az egészség ügyi rendszernek. Az elhízás gyakoriságának növekedése a kulturális és környezeti hatások változásával is összefüggésbe hozható: energiadús táplálékok, megnövekedett adagok, kevés testmozgás, táplálkozási rendellenességek (Tsigos, Heiner, Basdevant és mtsai, 2008).

A 4. táblázatban a vizsgált minta Testtömeg Indexének átlagát figyelhetjük meg, amelyből kiderül, hogy a nyíregyházi minta TTI-je alapján normális testsúllyal (24,77 / $<25,00)$ rendelkezik. Összehasonlítva a felnőtt magyar lakosság TTI átlagával $(27,3)$ (Országos Táplálkozás és Tápláltsági Állapot Vizsgálat, 2009) elmondható, hogy a nyíregyházi minta az országos átlag alatt van.

Az Eurostat (2008) adatai szerint Magyarország felnőtt lakosságának 53,2\%-a elhízott ( $\geq 25.00), 17.7$ \%-túlsúlyos ( $\geq 30.00$ ), Románia felnőtt lakosságának pedig 41,7\%a túlsúlyos, 8,7 \%-a pedig elhízott. Az Eurostat adatok azt mutatják, hogy a TTI alapján az ország lakosságának hány százaléka elhízott, a pontos TTI-ről nem beszél, ezért úgy véljük, hogy itt a két adat viszonyáról nem beszélhetünk (mert két különböző értékröl van szó).

4. Táblázat: A vizsgált minta TTI- ének átlaga

\begin{tabular}{|l|l|}
\hline & TTI átlag \\
\hline Gyergyószentmiklós & 25,45 \\
\hline Nyíregyháza & 24,77 \\
\hline
\end{tabular}

A gyergyószentmiklósi lakosság TTI-je a 25,45, ez az érték a túlsúlyosság kategóriájába sorolható $(25,00-29,99)$. Románia lakosságának TTI-nek átlaga az Eurostat statiszti- 
kái szerint szintén ebben a kategóriában van, elmondhatjuk tehát, hogy Gyergyószentmiklós lakosságának TTI-je nem tér el az országos átlagtól.

A kutatás nem érinti azon tényezők felderítését, amivel magyarázhatóak lennének az elhízás okai. Itt gondolunk, a táplálkozási szokásokra, a testmozgás gyakoriságára, biológiai, genetikai adottságokra, melyek a testsúly mértékét befolyásolják. Ábrám, Tar, és Finta (2013) kutatásai rávilágítanak arra, hogy a székelyföldi lakosság 60\%-a naponta kétszer vagy háromszor fogyaszt kenyeret, több mint $60 \%$-a pedig naponta használ füszereket, illetve konyhasót, utóbbi kettőnek egészségkárosító hatása van, a túlzott szénhidrát fogyasztásnak pedig a súlygyarapodásban lehet szerepe. A testmozgást illetően a legtöbbet sportoló korosztály a 18-25 évesek korosztálya, több mint 20\%-uk hetente két-három órán keresztül végez testmozgásokat, 20\%-uk hetente egy órát, 20\%-uk viszont egyáltalán semmilyen testmozgást nem végez. A 25-29, 30-39 évesek több mint negyven százaléka hanyagolja teljesen a testmozgást, a kor elörehaladtával ez a százalék 50- 60\%-ra nő.

A túlsúly és elhízás mindkét nemre jellemző, az Eurostat statisztikái alapján (a 27 tagállamból 19 ország lakosságának TTI-ére vonatkozó adatok) 19 tagállamból nyolc tagállamban a túlsúlyosak (TTI $\geq 25,00$ ) aránya magasabb volt a nők esetében, tíz tag államban az túlsúlyos férfiak aránya van többségben. Az elhízás (TTI $\geq 30,00)$ azonban minden tagállamban nemfüggő: a túlsúlyos férfiak aránya magasabb a túlsúlyos nők arányánál (kivétel Magyarország és Szlovénia) (EUROSTAT, 2008). (5. táblázat)

A vizsgált mintában a férfiak TTI-e magasabb a nők TTI-nél, a nők a normális súlykategóriába tartoznak, míg a férfiak a 27,07 értékü TTI-vel a túlsúlyos csoportban vannak. A gyergyószentmiklósi mintában (lásd 3. ábra) a férfiak TTI-e 27,15, ami 3,39-el nagyobb a nők TTI értékénél. Nyíregyházán a férfiak testtömeg indexe 26,77, 2,3-al több a nök TTI értékénél.

5. Táblázat: A vizsgált minta TTI -ének átlaga nem függvényében

\begin{tabular}{|l|l|} 
Nem & TTI átlag \\
\hline Férfi & 27,07 \\
\hline Nő & 24,07 \\
\hline
\end{tabular}

A TTI értéke, a túlsúly és elhízás prevalenciája a kor előrehaladtával mindkét nemnél nő. A férfiak elhízása körülbelül 30 éves koruktól időskorig tart. A nőknél általában a első terhességük idején kezdődik, elhízás szempontjából veszélyeztetett időszaknak számít a menopauza ideje (Belgyógyászati Szakmai Kollégium és Magyar Elhízástudományi Társaság, 2008). A fiatal 18-34 éves férfiak 41\%-ának TTI-e magasabb 25nél, 65 év felett ez az arány már eléri a 76 \%-ot. A nőknél szintén nő a TTI értéke a kor elörehaladtával, a fiatal nők 30 \%-ára jellemző az elhízás és a túlsúly (TTI $\geq 25,00$ ) (kevesebb, mint a hasonló korú férfiaknál), időskorra ez az arány $83 \%$-ra nő. (3. ábra)

A 6. táblázat a vizsgált minta TTI-t mutatja be a kor változásának függvényében. Az adatok jól mutatják, hogy mindkét városban a TTI a kor előrehaladtával nő. A gyer- 
gyószentmiklósi és nyíregyházi 18-35 éves korosztály a normális súlykategóriába tartozik, a gyergyószentmiklósi minta testtömeg indexének átlaga 23,69, ami magasabb a nyíregyházi minta átlagánál.

3. ábra. A TTI átlagértékei nem és lakhely szerint

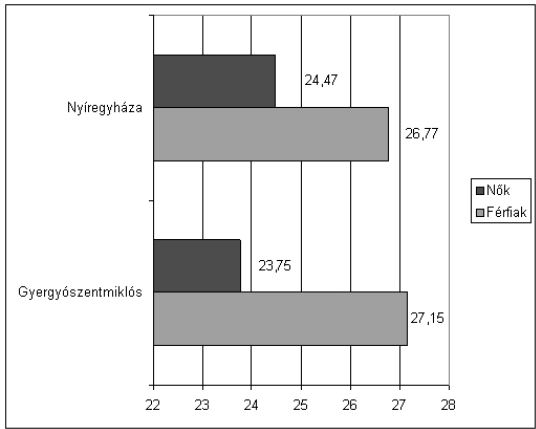

6. Táblázat: A TTI változása az életkor elörehaladtával

\begin{tabular}{|l|c|c|c|}
\hline & $18-35$ év & $36-65$ év & 66 év fölött \\
\hline Gyergyószentmiklós & 23,69 & 25,92 & 27,46 \\
\hline Nyíregyháza & 22,85 & 25,95 & 27,22 \\
\hline
\end{tabular}

\section{AZ ELHÍZÁS, MINT AZ AGYI-, SZÍV- ÉRRENDSZERI BETEGSÉGEK KIALAKULÁSÁNAK KOCKÁZATI TÉNYEZŐJE}

Az elhízás, a túlsúly egyike a szív-, érrendszeri megbetegedések kialakulásának kockázati tényezőjének. Emellett, elsőrendủ rizikófaktornak számít a magas koleszterinszint, a magas vérnyomás és a dohányzás (Jung és Egyed, 1998). Cardiovasculáris betegségek közé soroljuk a hipertóniát (magas vérnyomás), ischaemiás szívbetegséget, myocardiális infarktust, balszívfél-elégtelenséget, cor pulmonale betegségeket (Belgyógyázati Szakma Kollégium, és a Magyar Elhízástudományi Társaság, 2008).

Kutatásunkban az agyi-, és szívérrendszeri betegségek közül a hipertónia, szívinfarktus, szívkoszorúér- (koronária) megbetegedések, angina, egyéb szívbetegség, agyvérzés betegségek előfordulását vizsgáltuk a mintában, majd összefüggéseket kerestünk a TTI mértéke és a különböző betegségek elöfordulása között. (4. ábra) 
4. ábra. Magas vérnyomás és TTI közötti összefüggés (\%) (Az elmúlt 12 hónapban kezelte-e orvos magas vérnyomással?)

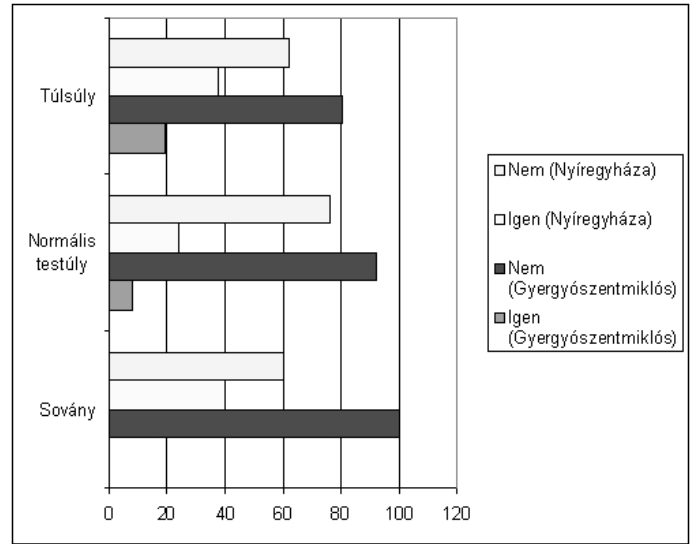

A magas vérnyomás és a TTI értéke között nem találtunk szignifikáns összefüggést $(\mathrm{p}=0,06)$. Gyergyószentmiklóson és Nyíregyházán (4. ábra) a TTI és magas vérnyomás közötti kapcsolat eltérést mutat. Nyíregyházán a sovány TTI kategóriába sorolható válaszadók 40\%-a volt kezelve magas vérnyomással, a normális testsúllyal rendelkezők 23,9\%-a a túlsúlyosak 37,5-a kereste fel orvosát ezzel a problémával. Gyergyószentmiklóson a magas vérnyomás betegségben szenvedők aránya nő a TTI értékének növekedésével, míg a normális testsúlyúak 7,8 \%-a szenved magas vérnyomás betegségtől, addig a túlsúlyosak 19,6\%-ánál jelenik meg ez a betegség.

Az 5. ábra a szívinfarktus és TTI közötti összefüggéseket ábrázolja, azonban a szívinfarktus és TTI között a szignifikanciaszint egyenlő 0,92, ez pedig a két változó közötti összefüggést kizárja. Mindkét mintában, a sovány kategóriába tartozók egyikének nem volt szívinfarktusa. A gyergyószentmiklósi minta normális testsúly kategóriába tartozók 2,7\%-ának, a túlsúlyos kategóriába tartozók 2,2\%-ának volt infarktusa. A nyíregyházi válaszadók 4,4\%-ánál (normális testsúly kategóriában) alakult ki szívinfarktus.

A koszoruér megbetegedést az érelmeszesedés okozza, az ütőerek falában zsírt és koleszterint tartalmazó lerakódások jönnek létre, amely hosszú távon az erek szűkületét vagy elzáródását okozhatják (Jung és Egyed, 1998).

A koszorúér megbetegedések a nyíregyházi mintára jellemzőbb, mint a gyergyószentmiklósi mintára, a sovány kategóriába tartozók 20\%-át, a normális testtömegüek 8,9 \%-át, a túlsúlyosak 10,2\%-át kezelték koszorúér megbetegedéssel. Az ábra alapján nincs összefüggés a túlsúly és a koszoruér megbetegedés között. A gyergyószentmiklósi minta esetében azonban megfigyelhető, hogy a normális testsúlyúak 1,4\%-a szenved koszorúér megbetegedésben, a túlsúlyosak esetében ez az arányszám 4,3\%-ra növekedik. (6. ábra) 
5. ábra. A szívinfarktus és a TTI közötti összefüggés (\%)

(Az elmúlt 12 hónapban kezelte-e orvos infarktussal?)

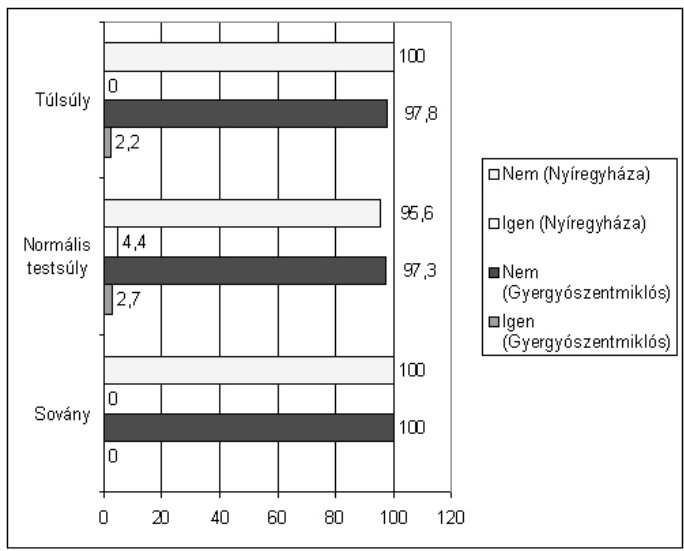

Az egyéb, más szívbetegségek (7. ábra) a nyíregyházi mintára nagyobb mértékben jellemző, a túlsúlyosak $10,2 \%$-a, a normális testsúlyúak $2,3 \%$-a, a soványak $20 \%$-a fordult az utóbbi 12 hónapban egyéb, más szívbetegséggel, mint a koszorúér megbetegedés, infarktus vagy hipertónia orvoshoz. Gyergyószentmiklóson kisebb arányban szenvednek egyéb szívbetegségekben.

6. ábra. A koszorúér betegségek és a TTI közötti összefüggés (\%) (Az elmúlt 12 hónapban kezelte-e orvos koszorúér megbetegedéssel?)

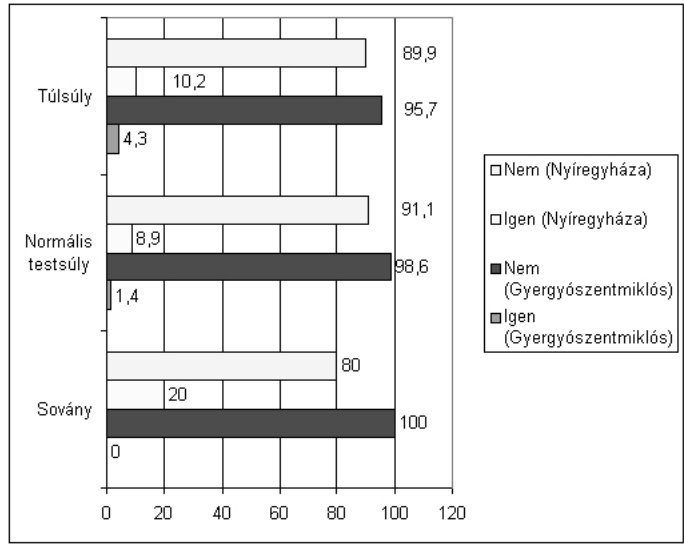


7. ábra. Más szívbetegségek és a TTI közötti összefüggés (\%) (Az elmúlt 12 hónapban kezelte-e orvos más szívbetegséggel?)

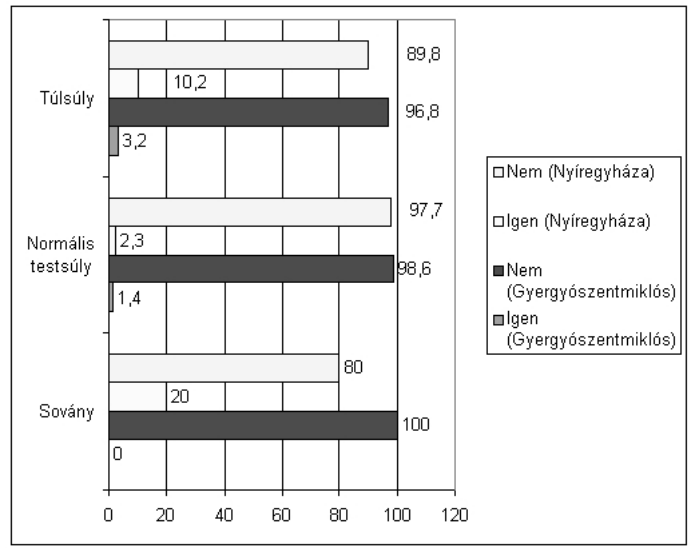

8. ábra: Az agyvérzés és a TTI közötti összefüggés (\%) (Az elmúlt 12 hónapban kezelte-e orvos agyvérzéssel?)

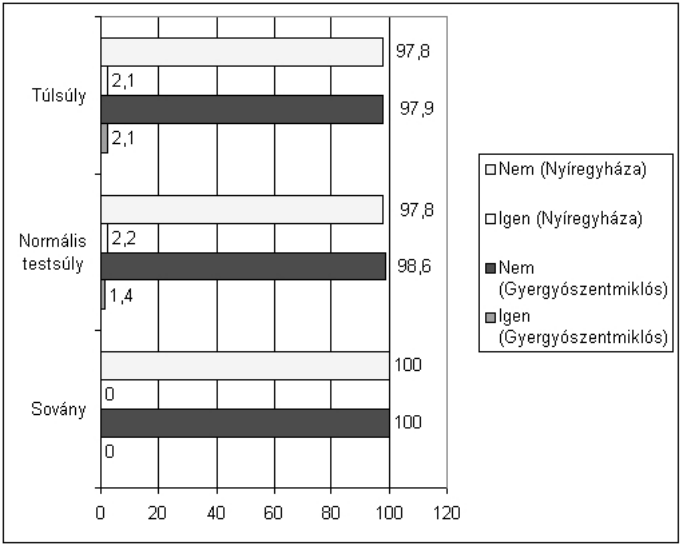

Az agyvérzés mindkét mintában a normális testsúlyúak és túlsúlyosak esetében jelentkezett. A gyergyószentmiklósi normál súlykategóriába tartozók 1,4%- ának, a túlsúlyosak 2,1 \%-ának volt agyvérzése, a nyíregyházi mintában a normál súlykategóriába tartozók aránya valamivel magasabb $(2,2 \%)$. (8. ábra) 


\section{KÖVETKEZTETÉSEK}

A kutatás eredményeként megállapíthatjuk, hogy az egész népességet érintő elhízás problémája alól a vizsgált minta sem kivétel. A nyíregyházi lakosság 24,77 (közel a normális testsúly felső értékéhez, a határértékhez) értékủ TTI-e alapján nem tartozik az elhízott, túlsúlyos kategóriába. Ettől függetlenül, megvizsgálva az agyi- és érrendszeri betegségek elöfordulását, láthattuk, hogy a magas vérnyomás, az infarktus, a koszorúér megbetegedések, egyéb szívbetegségek és az agyvérzés gyakrabban előfordult, mint a gyergyószentmiklósi mintában. Ez az első legszembetünőbb különbség a két minta között.

A gyergyószentmiklósi minta átlagos TTI-e 25.45, ez az érték már a túlsúlyos kategóriában található. A szív-, és érrendszeri betegségek közül a magas vérnyomás betegsége jellemzi a normális testsúlyúak $7.4 \%$-át ás a túlsúlyosak 19,6\%-át. A kisebb TTIel jellemző nyíregyházi lakosság nagyobb aránya szenved ebben a betegségben, a sovány kategóriába tartozók $20 \%$-ának magas vérnyomása van. A sovány kategóriába tartozó nyíregyházai mintában a szívbetegségek közül a koszorúér és egyéb szívbetegségek is megjelennek, szemben a sovány kategóriába tartozó gyergyószentmiklósi mintával, ahol egyetlen esetben sem jelennek meg ezek a szívbetegségek. A második különbség ebből adódik, a gyergyószentmiklósi mintában mindegyik betegség a normális testsúlyúak és a túlsúlyosak csoportjában figyelhető meg, a nyíregyháziaknál a sovány kategóriába tartozók is szív-, érrendszeri betegségben szenvednek.

A kutatásban felhasznált Életminőség- Háztartáspanel kérdőív nem méri fel a mintában résztvevők mentális állapotát, ezért az érrendszeri betegségek kialakulása és mentális állapot között nem tudunk megbízható összefüggést találni. Kopp Mária (2007) a Kelet- közép európai egészségparadoxon - tanulmánya rámutat arra, hogy a magyarországi középkorú népesség halálozási arányai magasabbak az ezredfordulón, mint az 1930-as években voltak. Az okokat tekintve jelentős szerepet tulajdonítanak a lelki, magatartási tényezőknek. A tanulmányban hangsúlyt kap a viszonylagos lemaradás, az iskolai végzettség és az egészségi állapot közötti szoros korreláció (Kopp, 2007). Kutatási eredményünk alapján a nyíregyházi minta iskolai végzettsége alacsonyabb, mint a gyergyószentmiklósi mintában résztvevőké és a szív- és érrendszeri betegségek magasabb arányban fordulnak elö ebben a mintában. Természetesen nem magyarázhatjuk a betegségek magasabb elörefordulási gyakoriságát kizárólag az iskolai végzettséggel, azonban a téma tágabb értelmezésében e tényező vizsgálatát is fontosnak tartanánk.

Harmadik különbségként megemlíthetjük, hogy a gyergyószentmiklósi mintában a betegségek előfordulásának gyakorisága a TTI értékével növekszik, míg a nyíregyházi mintában nem.

A kutatás nem érint minden kockázati tényezőt, amelyek a szív-, és érrendszeri betegségek kialakulásában szerepet játszanak, azért, hogy erről teljes képet kapjunk, további kutatások szükségesek. Azt tudjuk azonban, hogy Magyarország az Európai Unió tagországai közül az első helyen áll a szívbetegség okozta elhalálozás szempontjából és a szívbetegségben szenvedők magas arányát a nyíregyházi mintában is megfigyelhetjük. 


\section{Felhasznált irodalom}

1. Ábrám Z, Tar Gy., Finta H. - Országos egészség-felmérési program: miért nem lett belöle semmi? URL: http://eletmod.transindex.ro/?cikk=15911\&nyomtat=1, letöltve 2013.04.07

2. Ábrám Z., Tar Gy.: Impactul Programului National privind Evaluarea Starii de Sanatate a Populatiei asupra medicilor de familie din judetul Harghita, Practica Medicala- Vol VII, Nr. 4 (28), An 2012

3. Belgyógyászati Szakmai Kollégium, Magyar Elhízástudományi Társaság: Az Egészségügyi Minisztérium szakmai protokollja, Az elhízás diagnosztikája és kezelése, 2008, URL: http://www.kk.pte.hu/servlet/download?type=file\&id=430, letöltve 2013.04.07

4. Eurostat Statistical books (2008 edition): The life of women and and men in Europe, A statistical portrait, Luxembourg

5. Eurostat Statistical books (2009 edition): Health Statistics- Atlas on mortality in the European mortality

6. Eurostat Statistical books (2013 edition): The EU in the world 2013, A statistical portrait

7. Fábián G., Patyán L., Huszti É. (2012): Életminőség Nyíregyházán 2008-2010, Debreceni Egyetem, Orvos- és Egészségtudományi Centrum, Egészségügyi Kar, Nyíregyháza

8. INSSE Harghita, 2013

9. Jung J., Egyed Zs. I. (1998): Általános patológia, Marosvásárhely, Mentor Kiadó

10. Kopp, M. (2007). A kelet-közép-európai egészségparadoxon. In: Kállai, J., Varga, J., Oláh, A. (szerk.), Egészségpszichológia a gyakorlatban (pp. 51-64). Budapest: Medicina Kiadó.

11. National Institute for Food and Nutrition Science, National Diet and Nutritional Status Survey 2009 (OTÁP): Health is in the focus, April 27, 2010, http://www.oeti.hu/download/nationaldiet.pdf, letöltve 2013.04.07

12. Tsigos C., Hainer V., Basdevant A.m Finer N., Fried M., Elisabeth M, Micic D., Maislos M., Roman G., Schutz Y., Toplak H., Zahorska-Markiewicz B.: Management of Obesity in Adults: European Clinical Practice Guidelines, Obesity Facts 2008:1:106-116 http://easo.org/documents/OMTFManagementofObesityinAdults2008.pdf, letöltve 2013.04.07 